\title{
Reclassification of Agromyces fucosus subsp. hippuratus as Agromyces hippuratus sp. nov., comb. nov. and emended description of Agromyces fucosus
}

\author{
A. Ortiz-Martinez, ${ }^{1}$ J. M. Gonzalez, ${ }^{1}$ L. I. Evtushenko, ${ }^{2}$ V. Jurado, ${ }^{1}$ L. Laiz, ${ }^{1}$ \\ I. Groth ${ }^{3}$ and C. Saiz-Jimenez ${ }^{1}$ \\ ${ }^{1}$ Instituto de Recursos Naturales y Agrobiologia de Sevilla, CSIC, Apartado 1052, 41080 \\ Sevilla, Spain \\ ${ }^{2}$ All-Russian Collection of Microorganisms (VKM), G. K. Skryabin Institute of Biochemistry and \\ Physiology of Microorganisms, Russian Academy of Sciences, Pushchino, Moscow Region \\ 142292, Russia
}

Correspondence

C. Saiz-Jimenez saiz@irnase.csic.es
${ }^{3}$ Hans-Knöll-Institut für Naturstoff-Forschung, Beutenbergstrasse 11a, 07745 Jena, Germany

The taxonomic position of Agromyces fucosus subsp. hippuratus is revised on the basis of molecular and phenotypic data. Phylogenetic analysis based on 16S rRNA gene sequences, DNA-DNA relatedness values and differences from other species in phenotypic traits revealed in this and earlier studies suggested reclassification of $A$. fucosus subsp. hippuratus as a separate species, Agromyces hippuratus sp. nov., comb. nov. The type strain is VKM Ac- $1352^{\top}$ $\left(=\mathrm{JCM} 9087^{\top}\right)$. An emended description of Agromyces fucosus is given.
The genus Agromyces, with type species Agromyces ramosus, was established by Gledhill \& Casida (1969) for filamentous, nutritionally fastidious, catalase- and oxidase-negative soil isolates. Zgurskaya et al. (1992) emended the description of the genus and described two species each including two subspecies, Agromyces cerinus subsp. cerinus, A. cerinus subsp. nitratus, Agromyces fucosus subsp. fucosus and $A$. fucosus subsp. hippuratus, which are characterized by rapid growth on peptone/yeast extract medium and positive catalase and oxidase reactions. Although the proposal of A. cerinus and its subspecies was substantiated by numerical analysis and their respective DNA-DNA relatedness values, the description of $A$. fucosus subsp. hippuratus was based only on phenotypic traits (Zgurskaya et al., 1992). Subsequently, Suzuki et al. (1996) analysed DNA-DNA relatedness in representatives of the genus Agromyces and found that values between the type strains of $A$. fucosus subsp. fucosus and A. fucosus subsp. hippuratus were in the range $45-47 \%$, which is lower than the value of $70 \%$ usually considered to indicate delineation of separate species (Wayne et al., 1987). Recently, five additional Agromyces species have been described, Agromyces bracchium, Agromyces luteolus, Agromyces rhizospherae (Takeuchi \& Hatano, 2001), Agromyces aurantiacus (Li et al., 2003) and Agromyces albus (Dorofeeva et al., 2003).

The GenBank/EMBL/DDBJ accession number for the 16S rRNA gene sequence of Agromyces fucosus VKM Ac- $1345^{\top}$ is AY 158025 and that of Agromyces cerinus subsp. nitratus VKM Ac- $1351^{\top}$ is AY277619.
During a study to identify Agromyces strains isolated from caves, Laiz et al. (2000) performed phylogenetic analyses based on the nearly complete $16 \mathrm{~S}$ rRNA gene sequences of A. fucosus subsp. fucosus VKM Ac- $1345^{\mathrm{T}}$ (1473 bp; AY158025) and A. cerinus subsp. nitratus VKM Ac- $1351^{\mathrm{T}}$ (1465 bp; AY277619) obtained in this study and the 16S rRNA gene sequences of other Agromyces strains available from public DNA databases. The analysis was performed using the software package ARB (Ludwig et al., 1998) with the neighbour-joining algorithm and the results showed that A. fucosus subsp. fucosus VKM Ac- $1345^{\mathrm{T}}$ and $A$. fucosus subsp. hippuratus VKM Ac- $1352^{\mathrm{T}}$ are significantly distant (Fig. 1). They exhibited $96 \cdot 7 \%$ 16S rRNA gene binary sequence similarity, which is lower than the threshold usually reported for members of a single bacterial species (Stackebrandt \& Goebel, 1994; Roselló-Mora \& Amann, 2001). The $16 \mathrm{~S}$ rRNA gene sequence similarities between the type strains of different Agromyces species are in the range $96 \cdot 5-98 \cdot 5 \%$ based on sequences of over $1400 \mathrm{bp}$.

A degree of DNA-DNA relatedness between A. fucosus subsp. fucosus VKM Ac- $1345^{\mathrm{T}}$ and A. fucosus subsp. hippuratus VKM Ac- $1352^{\mathrm{T}}$ was determined by measuring the divergence between the thermal denaturation midpoint of homoduplex DNA and heteroduplex DNA $\left(\Delta T_{\mathrm{m}}\right)$ as described by De Ley et al. (1970). We found a significant $\Delta T_{\mathrm{m}}\left(5 \cdot 6^{\circ} \mathrm{C}\right)$ between $A$. fucosus subsp. fucosus and $A$. fucosus subsp. hippuratus, which is above the value of $5^{\circ} \mathrm{C}$ used to indicate separate species (Roselló-Mora \& Amann, 


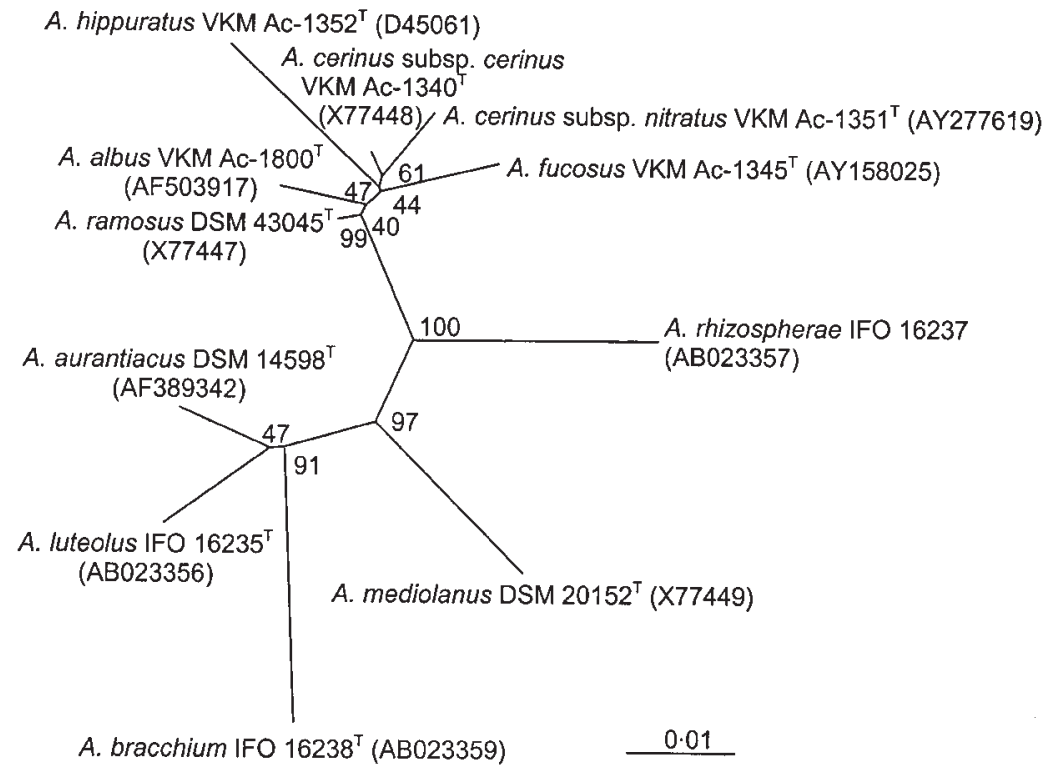

Fig. 1. Phylogenetic tree showing relationships between the 16S rRNA gene sequences of Agromyces type species. Accession numbers for the sequences are also given. Bootstrap numbers are percentages obtained from 1000 trials. Bar, 0.01 nucleotide substitutions per site.
2001). This result is in agreement with DNA-DNA relatedness values $(45-47 \%)$ reported for these strains by Suzuki et al. (1996). The above data demonstrate that A. fucosus subsp. fucosus and A. fucosus subsp. hippuratus belong to different genomic species (Wayne et al., 1987).

On the basis of previously published data, it was not possible unambiguously to conclude whether A. fucosus subsp. hippuratus represents a separate genomic species within the genus Agromyces, because its relationship with $A$. cerinus subsp. nitratus is vague. Our phylogenetic analysis based on $16 \mathrm{~S}$ rRNA gene sequences showed that A. fucosus subsp. hippuratus VKM Ac- $1352^{\mathrm{T}}$ is different from both $A$. cerinus subsp. nitratus VKM Ac- $1351^{\mathrm{T}}$ and $A$. cerinus subsp. cerinus VKM Ac- $1340^{\mathrm{T}}$ (Fig. 1), exhibiting $97 \cdot 8$ and $98 \cdot 4 \% 16 \mathrm{~S}$ rRNA gene sequence similarities to these strains, respectively. Investigation of DNA-DNA relatedness between $A$. fucosus subsp. hippuratus VKM Ac- $1345^{\mathrm{T}}$ and $A$. cerinus subsp. nitratus VKM Ac- $1352^{\mathrm{T}}$ revealed a $\Delta T_{\mathrm{m}}$ of $9.6^{\circ} \mathrm{C}$, suggesting these strains belong to different species (RosellóMora \& Amann, 2001). Similar analyses performed on the type strains of $A$. cerinus subsp. cerinus and $A$. cerinus subsp. nitratus revealed a small $\Delta T_{\mathrm{m}}\left(4 \cdot 1^{\circ} \mathrm{C}\right)$ and confirmed their close DNA-DNA relatedness, as reported by Zgurskaya et al. (1992) and Suzuki et al. (1996).

At the phenotypic level, A. fucosus subsp. hippuratus differs from $A$. fucosus subsp. fucosus and from both subspecies of A. cerinus with regard to cell wall teichoic acid composition, which are water-soluble carbohydrate-containing polymers covalently linked to peptidoglycan by phosphodiester bridges and which occur in many Gram-positive bacteria (Baddiley, 1972; Naumova et al., 2001). Two strains of $A$. fucosus subsp. hippuratus (VKM Ac- $1352^{\mathrm{T}}$ and VKM Ac1353) contained 1,5-poly(ribitol phosphate) with tetrasaccharide substituents (Gnilozub et al., 1994; Naumova et al., 2001), whereas four strains of A. fucosus subsp. fucosus (VKM Ac-1345 ${ }^{\mathrm{T}}$, VKM Ac-1346, VKM Ac-1347 and VKM
Ac-1349) contained 1,3-poly(glycerol phosphate) with $\beta$-N-acetylglucosamine substituents (Malysheva, 1994). Five analysed strains of $A$. cerinus subsp. cerinus (VKM Ac- $1340^{\mathrm{T}}$, VKM Ac-1342, VKM Ac-1343, VKM Ac-1344 and VKM Ac-1350) contained poly(arabitol phosphate) teichoic acid, and A. cerinus subsp. nitratus VKM Ac- $1351^{\mathrm{T}}$, the only known strain of this subspecies, contained poly(ribofuranosylribitol phosphate) polymer in the cell wall (Shashkov et al., 1993, 1995; Malysheva, 1994; Naumova et al., 2001). The structures and combinations of cell wall teichoic acids are considered of high taxonomic value and were shown to be usually species-specific in all actinomycete genera in which they were analysed (for references, see Naumova et al., 2001). These data are consistent with a clear physiological discrimination between A. fucosus subsp. hippuratus and other recognized species (Zgurskaya et al., 1992; Suzuki et al., 1996; Takeuchi \& Hatano, 2001; Li et al., 2003; Dorofeeva et al., 2003). In addition, representatives of the $A$. fucosus subspecies were reported to differ in polyamine composition (Altenburger et al., 1997); for instance, A. fucosus subsp. fucosus contained putrescine and 1,3-diaminopropane whereas $A$. fucosus subsp. hippuratus contained putrescine and spermidine.

Fatty acid profiles of the type strains of $A$. fucosus and $A$. hippuratus were analysed using the Sherlock Microbial Identification System (MIDI) (Sasser, 1991). They showed only slight differences in their percentages of iso- and anteiso-15:0 to 17:0 fatty acids, which appeared to be of little value for species differentiation. The cellular fatty acid compositions determined in A. fucosus subsp. hippuratus and $A$. fucosus subsp. fucosus are, respectively, as follows $(\%)$ : iso- $\mathrm{C}_{14: 0}, 0.9$ and $0.6 ; n-\mathrm{C}_{14: 0}, 0.2$ and $0 \cdot 4$; iso- $\mathrm{C}_{15: 0}$, $10 \cdot 5$ and $6 \cdot 4$; anteiso- $\mathrm{C}_{15: 0}, 51 \cdot 7$ and $47 \cdot 2 ; n-\mathrm{C}_{15: 0}, 0 \cdot 1$ and $0 \cdot 1$; iso- $\mathrm{C}_{16: 0}, 14 \cdot 3$ and $14 \cdot 6 ; n-\mathrm{C}_{16: 0}, 1 \cdot 5$ and $1 \cdot 0$; iso- $\mathrm{C}_{17: 0}$, $1 \cdot 9$ and $2 \cdot 3$; anteiso- $\mathrm{C}_{17: 0}, 18 \cdot 1$ and $27 \cdot 5 ; n-\mathrm{C}_{18: 0}, 0 \cdot 1$ and $0 \cdot 2$. 
Thus, based on the $16 \mathrm{~S}$ rRNA gene sequence analysis, DNADNA relatedness values and differences in phenotypic traits obtained in this and earlier studies (Zgurskaya et al., 1992; Suzuki et al., 1996; Takeuchi \& Hatano, 2001; Dorofeeva et al., 2003), we propose to reclassify A. fucosus subsp. hippuratus as a separate species, Agromyces hippuratus sp. nov., comb. nov. (type strain VKM Ac- $1352^{\mathrm{T}}$ ), and to emend the description of A. fucosus. The latter is restricted to strains assigned previously to A. fucosus subsp. fucosus (Zgurskaya et al., 1992).

\section{Description of Agromyces hippuratus sp. nov., comb. nov.}

Agromyces hippuratus (hip.pu.ra'tus. N.L. n. hippuratum hippurate; N.L. masc. adj. hippuratus pertaining to hippurate, relating to the ability to decompose hippurate).

Basonym: Agromyces fucosus subsp. hippuratus Zgurskaya et al. 1992.

The description is based on phenotypical data of Zgurskaya et al. (1992), Gnilozub et al. (1994), Malysheva (1994), Groth et al. (1996), Suzuki et al. (1996), Altenburger et al. (1997) and Dorofeeva et al. (2003). Colonies on nutrient media are opaque, entire, convex and usually penetrate into the agar media. Produces a yellow carotenoid pigment. Branching hyphae (width, $0.2-0.6 \mathrm{~mm}$ ) break into diphtheroid and rod-like, irregular, non-motile fragments. Aerobic, catalase- and oxidase-positive. Mesophilic; optimum growth is at $26-30{ }^{\circ} \mathrm{C}$. Strains are able to grow at $7{ }^{\circ} \mathrm{C}$; weak or no growth occurs at $37^{\circ} \mathrm{C}$. D-Arabinose, cellobiose, D-fructose, D-galactose, D-glucose, maltose, D-mannose, melezitose, melibiose, L-rhamnose, salicin, sucrose, trehalose and D-xylose are used for growth as sole carbon sources in a salt medium supplemented with $0 \cdot 1 \%(\mathrm{w} / \mathrm{v})$ yeast extract (Zgurskaya et al., 1992). Adonitol, dulcitol, mesoinositol, lyxose, D-mannitol, methyl $\beta$-D-arabinopyranoside and L-sorbose are not used as sole carbon sources in the same medium. Acids are produced from D-arabinose, glycerol and L-rhamnose; no acid production from cellobiose, inulin, lactose, maltose, raffinose, D-ribose, salicin or trehalose. Acid production from L-arabinose and sucrose is variable. Fumarate, hippurate, malate and pyruvate are utilized. No alkaline reactions with ascorbate, citrate, gluconate, oxalate, propionate, salicylate, succinate and tartrate are observed; some strains show positive reaction with trans-aconitate. Nitrate is reduced to nitrite and tyrosinase is produced. Aesculin, hypoxanthine and starch are hydrolysed. Adenine, elastin, guanine, pectin, testosterone, urea and xanthine are not decomposed or hydrolysed. Casein is usually not hydrolysed. Indole test is negative. No growth occurs on media supplemented with $5 \% \mathrm{NaCl}, 0.01 \%$ sodium azide or $0.0175 \%$ potassium tellurite. The major menaquinone is MK-12 with a minor amount of MK-13. Polyamine content is low; putrescine and spermidine are predominant compounds (data for the type strain only). Cell wall sugars are rhamnose, galactose and trace mannose. Cell wall contains 1,5-poly(ribitol phosphate) teichoic acid. The $\mathrm{G}+\mathrm{C}$ content of the DNA is about $71 \mathrm{~mol} \%$. Isolated from soil.

The type strain is VKM Ac- $1352^{\mathrm{T}}\left(=\mathrm{JCM} 9087^{\mathrm{T}}\right)$. The GenBank/EMBL/DDBJ accession number for the 16S rRNA gene sequence of this strain is D45061.

\section{Emended description of Agromyces fucosus}

The description is based on phenotypical data of Zgurskaya et al. (1992), Malysheva (1994), Groth et al. (1996), Suzuki et al. (1996), Altenburger et al. (1997) and Dorofeeva et al. (2003).

Colonies on nutrient media are opaque, entire and convex, and occasionally penetrate into the agar media. Produces a yellow carotenoid pigment. Branching hyphae (width, $0 \cdot 2-0.6 \mathrm{~mm}$ ) break into diphtheroid and rod-like, irregular, non-motile fragments. Catalase- and oxidase-positive. Mesophilic; optimum growth is at $26-30{ }^{\circ} \mathrm{C}$. Strains are able to grow at $7{ }^{\circ} \mathrm{C}$; no or weak growth occurs at $37^{\circ} \mathrm{C}$. D-Arabinose, cellobiose, D-fructose, D-galactose, D-glucose, maltose, D-mannose, melezitose, methyl D-glucoside, L-rhamnose, salicin, sucrose, trehalose and D-xylose are used for growth as sole carbon sources in a salt medium supplemented with $0 \cdot 1 \%(\mathrm{w} / \mathrm{v})$ yeast extract (Zgurskaya et al., 1992). Dulcitol, erythritol, lyxose, D-mannitol, methyl- $\beta$-D-arabinopyranoside and L-sorbose are not used as sole carbon sources in the same medium. Some strains, including the type strain, use melibiose for growth, whereas adonitol and meso-inositol are not used by most of the strains, including the type strain. Acids are usually produced from L-arabinose, cellobiose, glycerol, inulin, lactose, maltose, L-rhamnose, salicin, sucrose and D-xylose by most strains (reactions of the type strain are positive or variable). Acetate, malate and pyruvate are utilized. Alkaline reactions with fumarate and propionate are variable (type strain is positive). Some strains utilize citrate and succinate (type strain is negative). Ascorbate, trans-aconitate, gluconate, oxalate, salicylate and tartrate are not utilized. Production of $\mathrm{H}_{2} \mathrm{~S}$ is variable; the type strain shows a positive reaction. Arbutin, aesculin and starch are hydrolysed; adenine, elastin, guanine, pectin, testosterone, urea and xanthine are not decomposed or hydrolysed. Hippurate, hypoxanthine, Tween 40 and tyrosine are decomposed by some strains, including the type strain. Casein is usually not hydrolysed. Indole test is negative. Nitrate reduction test is negative or weak reaction is observed. No growth occurs on media supplemented with $5 \% \mathrm{NaCl}, 0 \cdot 01 \%$ sodium azide or $0.0175 \%$ potassium tellurite. The major menaquinone is MK-12; the second most common component is MK-13. Polyamine content is low; putrescine and 1,3-diaminopropane are the predominant compounds (data for the type strain only). Cell wall sugars are galactose, rhamnose, fucose and minor mannose (type strain); glucose may occur but fucose is lacking in other strains. Cell wall contains 1,3-poly(glycerol phosphate) teichoic acid. The $\mathrm{G}+\mathrm{C}$ content of the DNA is $70-72 \mathrm{~mol} \%$. Isolated from soil. 
The type strain is VKM Ac- $1345^{\mathrm{T}}\left(=\mathrm{DSM} 8597^{\mathrm{T}}\right)$. The GenBank accession number for the $16 \mathrm{~S}$ rRNA gene sequence of this strain is AY158025.

\section{Acknowledgements}

This research was funded by the European Commission project EVK4CT2000-00028 and the Spanish projects BTE2002-04492-C02-01 and REN2002-00041. J. M. G. acknowledges support by Ramon y Cajal Programme and V. J. and L. L. from I3P (European Social Fund).

\section{References}

Altenburger, P., Kämpfer, P., Akimov, V. N., Lubitz, W. \& Busse, H.-J. (1997). Polyamine distribution in actinomycetes with group $B$ peptidoglycan and species of the genera Brevibacterium, Corynebacterium and Tsukamurella. Int J Syst Bacteriol 47, 270-277.

Baddiley, J. (1972). Teichoic acids in cell walls and membranes of bacteria. Essays Biochem 8, 35-77.

De Ley, J., Cattoir, H. \& Reynaerts, A. (1970). The quantitative measurement of DNA hybridization from renaturation rates. Eur J Biochem 12, 133-142.

Dorofeeva, L. V., Krausova, V. I., Evtushenko, L. I. \& Tiedje, J. M. (2003). Agromyces albus sp. nov., isolated from a plant (Androsace sp.). Int J Syst Evol Microbiol 53, 1435-1438.

Gledhill, W. E. \& Casida, L. E. (1969). Predominant catalase-negative soil bacteria. III. Agromyces, gen. nov., microorganisms intermediary to Actinomyces and Nocardia. Appl Microbiol 18, 340-349.

Gnilozub, V. A., Streshinskaia, G. M., Evtushenko, L. I., Naumova, I. B. \& Shashkov, A. S. (1994). 1,5-Poly(ribitol phosphate) with tetrasaccharide substituents in the cell wall of Agromyces fucosus ssp. hippuratus. Biokhimiya 59, 1892-1899 (in Russian).

Groth, I., Schumann, P., Weiss, N., Martin, K. \& Rainey, F. A. (1996). Agrococcus jenensis gen. nov., sp. nov., a new genus of actinomycetes with diaminobutyric acid in the cell wall. Int J Syst Bacteriol 46, 234-239.

Laiz, L., Groth, I., Schumann, P., Zezza, F., Felske, A., Hermosin, B. \& Saiz-Jimenez, C. (2000). Microbiology of the stalactites from Grotta dei Cervi, Porto Badisco, Italy. Int Microbiol 3, 25-30.

Li, W.-J., Zhang, L.-P., Xu, P., Cui, X.-L., Xu, L.-H., Zhang, Z., Schumann, P., Stackebrandt, E. \& Jiang, C.-L. (2003). Agromyces aurantiacus sp. nov., isolated from a Chinese primeval forest. Int J Syst Evol Microbiol 53, 303-307.
Ludwig, W., Strunk, O., Klugbauer, S., Klugbauer, N., Weizenegger, M., Neumaier, J., Bachleitner, M. \& Schleifer, K. H. (1998). Bacterial phylogeny based on comparative sequence analysis. Electrophoresis 19, 554-568.

Malysheva, V. A. (1994). Teichoic and lipoteichoic acids of agromycetes. $\mathrm{PhD}$ thesis, Lomonosov Moscow State University (in Russian).

Naumova, I. B., Shashkov, A. S., Tul'skaya, E. M., Streshinskaya, G. M., Kozlova, Yu, I., Potekhina, N. V., Evtushenko, L. I. \& Stackebrandt, E. (2001). Cell wall teichoic acids: structural diversity, species-specificity in the genus Nocardiopsis and chemotaxonomic perspective. FEMS Microbiol Rev 25, 269-284.

Roselló-Mora, R. \& Amann, R. (2001). The species concept for prokaryotes. FEMS Microbiol Rev 25, 39-67.

Sasser, M. (1991). MIS Whole Cell Fatty Acid Analysis by Gas Chromatography. Newark, DE: Microbial ID Inc.

Shashkov, A. S., Malysheva, V. A., Naumova, I. B., Streshinskaya, G. M. \& Evtushenko, L. I. (1993). Poly(ribofuranosylribitol phosphate) in cell wall of Agromyces cerinus subsp. nitratus VKM Ac-1351. Bioorg Khim 19, 433-438.

Shashkov, A. S., Streshinskaya, G. M., Gnilozub, V. A., Evtushenko, L. I. \& Naumova, I. B. (1995). Poly(arabitol phosphate) teichoic acid in the cell wall of Agromyces cerinus subsp. cerinus VKM Ac- $1340^{\mathrm{T}}$. FEBS Lett 371, 163-166.

Stackebrandt, E. \& Goebel, B. M. (1994). Taxonomic note: a place for DNA-DNA reassociation and $16 \mathrm{~S}$ rRNA sequence analysis in the present species definition in bacteriology. Int J Syst Bacteriol 44, 846-849.

Suzuki, K., Sasaki, J., Uramoto, M., Nakase, T. \& Komagata, K. (1996). Agromyces mediolanus sp. nov., nom. rev., comb. nov., a species for "Corynebacterium mediolanum" Mamoli 1939 and for some aniline-assimilating bacteria which contain 2,4-diaminobutyric acid in the cell wall peptidoglycan. Int J Syst Bacteriol 46, 88-93.

Takeuchi, M. \& Hatano, K. (2001). Agromyces luteolus sp. nov., Agromyces rhizospherae sp. nov. and Agromyces bracchium sp. nov., from the mangrove rhizosphere. Int J Syst Evol Microbiol 51, 1529-1537.

Wayne, L. G., Brenner, D. J., Colwell, R. R. \& 9 other authors (1987). Report of the ad hoc committee on reconciliation of approaches to bacterial systematics. Int J Syst Bacteriol 37, 463-464.

Zgurskaya, H. I., Evtushenko, L. I., Akimov, V. N., Voyevoda, H. V., Dobrovolskaya, T. G., Lysak, L. V. \& Kalakoutskii, L. V. (1992). Emended description of the genus Agromyces and description of Agromyces cerinus subsp. cerinus sp. nov., subsp. nov., Agromyces cerinus subsp. nitratus sp. nov., subsp. nov., Agromyces fucosus subsp. fucosus sp. nov., subsp. nov., Agromyces fucosus subsp. hippuratus sp. nov., subsp. nov. Int J Syst Bacteriol 42, 635-641. 